\title{
PRIMARY SCHOOL CURRICULUM DEVELOPMENT ORIENTATION IN THE PERSPECTIVE OF MILLER AND SELLER MODEL OF CURRICULUM
}

\author{
Agustinus Tanggu Daga \\ STKIP Weetebula Sumba NTT, Indonesia \\ agus_daga@yahoo.com

\section{ORIENTASI PENGEMBANGAN KURIKULUM SEKOLAH DASAR DALAM PERSPEKTIF KURIKULUM MILLER DAN SELLER}

\section{ARTICLE HISTORY}

Submitted:

11 Agustus 2020

$11^{\text {th }}$ Agust 2020

Accepted:

16 Oktober 2020

$16^{\text {nd }}$ October 2020

Published:

26 Oktober 2020

$26^{\text {th }}$ October 2020

Abstract: This research aims to describe the theoretical perspective of Miller and Seller on curriculum development at primary schools. The literature study method was applied to collect the data from relevant resources. This research finds that Miller and Keller's curriculum orientation involves transmission, transaction, and transformation. The curriculum development for primary schools in the transmission orientation emphasizes the transfer of knowledge, skills, and values to students through learning subjects. Its learning process focuses on teachers while its learning strategy is expository and its learning evaluation utilizes traditional test instruments. The emphasis of transaction orientation is the interaction between curriculum and students. The teacher plays the role of facilitator to assist students in constructing knowledge. The learning strategy used is scientific approach with active, collaborative, and inquiry learning methods. Then, the learning evaluation uses authentic assessment. Whereas, the curriculum development in the transformation orientation emphasizes the students' personal and social transformation in which its learning strategy is implemented to encourage students to find the meaning and value of learning processes as well as to apply them in the real life. The teacher plays a role as a motivator and learning facilitator and its learning evaluation is based on the authentic assessment by emphasizing performance and behavior appraisal of primary school students. Finally, this research concludes that the primary school curriculum in transmission orientation is an academic subject curriculum that emphasizes an integrated curriculum organization. The primary school curriculum in transaction orientation is designed for solving social problems by using the scientific paradigm. The primary school curriculum in transformation orientation is designed in order that students are able to carry out personal and social transformation holistically.

Keywords: curriculum, transmission, transaction, transformation

Abstrak: Penelitian ini bertujuan memaparkan secara teoritik perspektif Miller dan Seller dalam pengembangan kurikulum di sekolah dasar. Penelitian ini menggunakan metode studi kepustakaan. Data dikumpulkan dari literatur yang relevan. Penelitian menemukan bahwa orientasi kurikulum Miller dan Seller meliputi tranmisi, transaksi dan transformasi. Pengembangan kurikulum untuk sekolah dasar dalam orientasi transmisi menekankan transfer pengetahuan, keterampilan, nilai-nilai kepada siswa yang didesain dalam mata pelajaran. Proses pembelajaran berpusat pada guru. Strategi pembelajaran adalah ekspositori, dan evaluasi pembelajaran menggunakan instrument tes tradisional. Penekanan orientasi transaksi adalah interaksi antara kurikulum dan siswa. Peran guru adalah fasilitator untuk membantu siswa mengonstruksi pengetahuan. Strategi pembelajaran menggunakan pendekatan ilmiah dengan metode pembelajaran aktif, kolaboratif dan inkuiri. Evaluasi pembelajaran menggunakan penilaian autentik. Pengembangan kurikulum dalam orientasi transformasi menekankan transformasi pribadi dan sosial siswa. Strategi pembelajaran diimplementasikan untuk mendorong siswa menemukan makna dan nilai proses pembelajaran serta menerapkan dalam kehidupan nyata. Peran guru adalah motivator dan fasilitator pembelajaran. Evaluasi pembelajaran berbasis penilaian autentik dengan penekanan pada penilaian kinerja dan sikap siswa sekolah dasar. Akhirnya penelitian ini menyimpulkan bahwa kurikulum sekolah dasar dalam orientasi transmisi merupakan kurikulum subjek akademik yang menekankan organisasi kurikulum secara terpadu. Kurikulum sekolah dasar dalam orientasi transaksi 
didesain untuk pemecahan masalah sosial dengan menggunakan paradigma santifik. Kurikulum sekolah dasar dalam orentasi transformasi didesain agar siswa mampu melakukan transformasi pribadi dan sosial secara holistik.

Kata Kunci: kurikulum, transmisi, transaksi, transformasi

\section{CITATION}

Daga, A.T. (2020). Primary School Curriculum Development Orientation in the Perspective of Miller And Seller Model of Curriculum. Primary: Jurnal Pendidikan Guru Sekolah Dasar, 9 (5), 645-662. DOI: http://dx.doi.org/10.33578/jpfkip.v9i5.7987.

\section{PENDAHULUAN}

Kurikulum memiliki peran yang penting dan strategis dalam mencapai tujuantujuan pendidikan. Kurikulum memiliki peran konservatif, evaluatif dan kreatif dalam pendidikan. Peranan tersebut terkandung di dalam perencanaan, implementasi dan evaluasi kurikulum. Menurut J. C. Richard (Wahyuni, 2016) bahwa "curriculum development process includes the design, development, implementation and evaluation of curricula". Pengembangan kurikulum dalam institusi pendidikkan meliputi perencanaan, implementasi, evaluasi kurikulum. Dalam pengembangan kurikulum sering digunakan model untuk menggambarkan elemen-elemen kurikuum, hubungan antarelemen serta proses pengembangan dan implementasi kurikulum.

Pengembangan kurikulum sangat penting bagi penyelenggaraan pendidikan di sekolah dasar. Pengembangan kurikulum bertujuan untuk memberi pijakan atau dasar yang kuat bagi kurikulum pendidikan di sekolah dasar. Jika pendidikan diibaratkan sebagai sebuah rumah maka pengembangan kurikulum adalah dasar atau fondasinya. Menurut Bahri (2011) fungsi dasar atau landasan pengembangan kurikulum adalah seperti fondasi sebuah bangunan. Berkualitas atau tidaknya kurikulum yang didesain oleh institusi pendidikan sangat ditentukan oleh dasar pengembangan kurikulum yang kuat. Agar kurikulum di sekolah dasar menjadi kurikulum yang berkualitas maka kurikulum harus dibangun atas dasar atau andasan yang kuat. Menurut Winarso (2017) landasan pengembangan kurikulum adalah landasan filosofis, landasan psikologis, dan landasan sosial-budaya. Landasan filosofis adalah perennialisme, esensialisme, progresivisme, dan rekonstruktivisme. Landasan psikologis meliputi psikologi perkembangan dan psikologi belajar. Landasan sosial-budaya merupakan nilai-nilai yang hidup dan dianut dalam masyarakat yang memberikan karakteristik dan budaya masyarakat.

$$
\text { Lebih jauh, Shofiyah }
$$
menyatakan bahwa pengembangan kurikulum adalah proses yang menentukan bagaimana kurikulum akan dilaksanakan. Artinya, agar kurikulum berhasil sesuai dengan tujuan yang ditetapkan maka kurikulum membutuhkan dasar pengembangan kurikulum. Maka pengembangan kurikulum mendasari desain kurikulum pada sekolah dasar. Pengembangan kurikulum yang berkualitas akan menghasilkan kurikulum yang berkualitas, selaras dengan kebutuhan masyarakat pendidikan serta perkembangan ilmu pengetahuan dan teknologi. Dalam konteks pengembangan kurikulum tersebut Miller dan Seller (1985) mengatakan bahwa jika institusi pendidikan (sekolah dasar) mengembangkan kurikulum maka proses pengembangan kurikulum itu merupakan proses menetapkan tujuan dan sasaran, mengidentifikasi konten yang sesuai, dan memilih strategi belajar-mengajar. Komponen kurikulum pada dasarnya meliputi tujuan, mataeri, strategi atau metode, dan evaluasi. Pengembangan komponen-komponen tersebut merupakan pengembangan kurikulum. 
Selain itu, pengembangan kurikulum memberi arah pada desain kurikulum dalam mencapai tujuan pendidikan. Kurikulum merupakan alat yang efektif untuk mencapai tujuan-tujuan pendidikan karena dalam kurikulum terdapat tujuan, materi, strategi atau metode dan evaluasi pendidikan. Dalam konteks itulah Arif Munandar menyatakan bahwa kurikulum adalah rencana pelajaran yang diberikan kepada pendidik untuk diterapkan pada siswa menjadi manusia yang terampil, kreatif, inovatif dan aktif dalam menjawab kebutuhan dan masalah kehidupan (Munandar, 2017). Pengembangan kurikulum yang dilaksanakan di sekolah dasar mengarahkan kurikulum kepada tujuan yang ditetapkan di sekolah dasar. Kurikulum memiliki posisi sentral dalam seluruh proses pendidikan. Kurikulum mengarahkan segala bentuk kegiatan pendidikan untuk tercapainya tujuan-tujuan pendidikan. Karena itu Mauritz Johnson (Ahid, 2006) mengatakan bahwa kurikulum merupakan suatu rencana pendidikan, memberikan pedoman dan pegangan tentang jenis, lingkup, dan urutan isi, serta proses pendidikan. Senada dengan pendapat tersebut Oemar Hamalik (Ndeot, 2019) menegaskan bahwa pengembangan kurikulum merupakan perencanaan kesempatan belajar yang bertujuan memfasilitasi siswa ke arah perubahan-perubahan yang diinginkan dan menilai sampai mana perubahan-perubahan itu telah terjadi pada diri siswa.

Pengembangan kurikulum memiliki kaitan yang erat dengan pembelajaran, baik dalam perancanaan, implementasi maupun evaluasi. Pengembangan kurikulum perlu dilaksanakan oleh sekolah dasar dalam rangka meningkatkan kualitas pendidikan, secara khusus kualitas pembelajaran. Karena itu implementasi kurikulum meliputi tiga aktivitas utama yaitu pengembangan program, pelaksanaan pembelajaran, dan evaluasi (Andiyanto, 2017). Menurut Ornstein dan Hunkins (2018) pengembangan kurikulum perlu dirancang sedemikian rupa sehingga siswa memiliki banyak kesempatan untuk memiliki pengalaman belajar, sehingga pengembangan kurikulum harus mempertimbangkan keterampilan dan strategi belajar siswa. Kurikulum memiliki kaitan yang kuat dan erat dengan pembelajaran di sekolah dasar. Hal ini sejalan dengan konsep kurikulum yang dikemukakan Ronald C. Doll (Wafi, 2017) yang menyatakan bahwa "the curriculum has changed from content of courses study and list of subject and courses to all experiences which are offered to learners under the auspices or direction of school'. Kurikulum dipandang sebagai pengalaman belajar yang ditempuh oleh siswa dalam bimbingan sekolah.

Dalam konteks kaitan antara kurikulum dan pembelajaran Oliva dan Gordon (2013) mengatakan bahwa kurikulum berkaitan dengan "apa" sedangkan pembelajaran berkaitan dengan "bagaimana". Kaitan antara kurikulum dan pembelajaran dilukiskan Oliva dan Gordon dalam empat model relasi yaitu dualistic model, interlocking models, concentric models, and cyclical models. Memang Dalam model dualistic, kurikulum dan pembelajaran merupakan dua konsep yang terpisah dan masing-masing berdiri sendiri. Namun modelmodel yang lain kurikulum dan pembelajaran menunjukan saling terkait. Dalam, interlocking models kurikulum dan pembelajaran memiliki posisi yang sama, tetapi keduanya saling mempengaruhi dimana keberhasilan pembelajaran dipengaruhi oleh perencanaan kurikulum yang baik, sebaliknya perencanaan kurikulum yang baik harus mempertimbangkan pembelajarannya. Dalam concentric models, kurikulum dan pembelajaran saling menyatu dengan kemungkinan pembelajaran berada dalam kurikulum atau kurikulum berada dalam pembelajaran. Sedanglan dalam cyclical models, kurikulum dan pembelajaran memiliki hubungan timbal balik dan saling mempengaruhi, dimana segala yang ditentukan dalam kurikulum akan menjadi dasar dalam proses pelaksanaan pembelajaran, dan 
sebaliknya yang terjadi dalam pembelajaran dapat memengaruhi keputusan kurikulum selanjutnya. Dan sejalan dengan hal tersebut dalam penelitiannya, Zulhafizh (2020) menemukan bahwa kurikulum merupakan panduan dalam menjalankan tugas pembelajaran di sekolah. Kurikulum dirancang sebagai sebuah perangkat rencana danpenyelenggaraan pembelajaran untuk mencapai tujuan pendidikan karena kurikulum menjadi payung dalam kegiatan pembelajaran.

Dalam mendefinisikan kurikulum Miller dan Seller sepakat dengan Saylor dan Alexander (1974), bahwa kurikulum merupakan rencana untuk menyediakan rangkaian kesempatan belajar untuk mencapai tujuan yang luas dan tujuan spesifik. Mereka juga sejalan dengan Tanner and Tanner (1980) bahwa kurikulum merupakan rekonstruksi pengetahuan dan pengalaman yang dikembangkan secara sistematis yang digasilitasi oleh sekolah untuk memungkinkan siswa meningkatkan kontrol atas pengetahuan dan pengalamanya. Meskipun demikian Miller dan Seller (1985) mendefinisikan kurikulum sebagai "an explicitly and implicitly intentional set of interactions designed to facilitate learning and development and to impose meaning on experience". Kurikulum merupakan serangkaian interaksi yang disengaja dirancang secara eksplisit dan implisit untuk memfasilitasi

\section{KAJIAN TEORETIS}

Pengembangan kurikulum dilaksanakan menurut perpektif tertentu. Jhon P. Miller (Miller and Seller, 1985) melalui buku The Educational Spectrum mengemukakan tujuh orientasi khusus dalam pengembangan kurikulum, yaitu orientasi perilaku (behavioral), mata pelajaran atau disiplin, sosial, perkembangan, proses kognitif, humanistik, dan transpersonal. Konsep orientasi khusus kurikulum tersebut mengekspresikan sudut pandang tertentu dalam kaitannya dengan konsep tujuan pendidikan, konsep tentang pembelajaran dan pengembangan dan untuk mendorong makna pada pengalaman belajar siswa.

Dalam konteks pengembangan kurikulum Miller dan Seller (1985) mendeskripsikan pengembangan kurikulum sebagai sebuah proses yang meliputi orientasi, pengembangan, implementasi, dan evaluasi dimana pengembangan kurikulum dikombinasikan dari model transmisi, model transaksi dan model transformasi. Kurikulum dipandang sebagai rangkaian interaksi sadar (intentional interactions) yang bersifat eksplisit maupun implisit yang didesain untuk memfasilitasi belajar siswa dan perkembangan siswa, serta untuk memberikan arti (meaning) pada pengalaman (Nurdi (2014: 19). Ketiga orientasi kurikulum - transmisi, transaksi dan transformasi- dapat diimplementasikan dalam pengembangan kurikulum sekolah dasar. Penelitian ini hendak memaparkan pengembangann kurikulum di sekolah dasar menurut orientasi pengembangan kurikulum Miller dan Seller. Fokus penelitian ini adalah pada dua pertanyaan utama, yaitu: 1) bagaimana orientasi pengembangan kurikulum menurut Miller dan Seller; 2) bagaimana pengembangan kurikulum sekolah dasar dalam menurut orientasi pengembangan kurikulum Miller dan Seller.

peserta didik, konsep tentang proses belajar, konsep tentang lingkungan belajar, konsep tentang peran guru atau pendidik, konsep tentang mengevaluasi belajar. Orientasi kurikulum akan memberi pijakan dan arah bagi pengembangn kurikulum untuk mendesain kurikulum dalam mencapai tujuan pendidikan. Lebih lanjut Miller dan Seller (Nurdin, 2014) konsep tujuan pendidikan berkaitan dengan arah kegiatan pendidikan, artinya hendak dibawa kemana siswa yang dididik itu. Konsep tentang anak berkaitan dengan apakah 
anak dipandang sebagai organisme yang aktif atau pasif. Konsep tentang proses pembelajaran bertalian dengan apakah proses pembelajaran merupakan sebuah proses transformasi ilmu pengetahuan atau mengubah perilaku anak. Konsep tentang lingkungan berlajar berkaitan dengan apakah lingkungan belajar dikelola secara formal atau secara bebas yang dapat memungkinkan anak bebas belajar. Konsep tentang peranan guru berhubungan dengan apakah guru berperan sebagai instruktur yang kuat atau guru sebagai fasilitator pembelajaran. Konsep tentang evaluasi belajar berkaitan dengan apakah alat ukur yang digunakan untuk menentukan keberhasilan peserta didik.

Para pendidik dalam berbagai jenjang pendidikan umumnya mengikuti dua atau tiga orientasi kurikulum dalam program pengembangan kurikulum. Hal ini akan membantu pendidik untuk memahami hubungan antara praktik kurikulum dengan konteks filosofis, psikologis, dan sosial yang membentuk kurikulum tersebut. Miller dan Seller (1985) membagi orientasi pengembangan kurikulum untuk mendesian pembelajaran meliputi transmisi (transmission), transaksi (transaction), dan transformasi (transformation) yang berbeda dalam konteks, tujuan, pengalaman belajar, peran guru, dan evaluasi.

\section{Orientasi Transmisi Pengembangan Kurikulum}

Filsafat empiris yang menjadi akar orientasi transmisi berasal dari yunani kuno. Namun orientasi filsafat ini menjadi menonjol ketika dikembangkan oleh para filsuf seperti Francis Bacon dan John Locke hinggal filsafat analitik. Secara filosofi, orientasi transmisi memiliki akar filosofis dalam positivisme logis yang mengusung pandangan atomistik tentang realitas (materi pelajaran) dipecah menjadi beberapa bagian yang terpisah. Dalam konteks psikologi, akar orientasi transmisi ditemukan dalam pandangan Thorndike dan Skinner dimana keduanya mengembangkan orientasi perilaku untuk belajar (behaviorisme), dan secara politik transmisi ini terkait dengan pandangan konservatisme. Maka tujuan pengembangan kurikulum terdiri dari tiga yaitu a) tujuan tanggungjawab sosial, b) tujuan pengembangan dimana siswa dapat mengidentifikasi bidang kepedulian sosial dan berpartisipasi dalam proyek yang menangani masalah sosial, c) tujuan instruksional, dimana siswa dapat mengembangkan keterampilan dalam berbagai proyek yang berorientasi memecahkan masalah sosial (Miller and Seller, 1985).

Dalam orientasi transmisi, fungsi pendidikan adalah untuk mengirimkan fakta, keterampilan, dan nilai-nilai kepada siswa. Transmisi tersebut menurut Miller dan Seller (Hadijaya, 2015) bertujuan agar peserta didik dapat menguasai materi mata pembelajaran di sekolah dengan mempelajari buku teks pelajaran, penguasaan keterampilanketerampilan dasar, nilai-nilai budaya tertentu dan moral yang berkembang di masyarakat, dan pengaplikasian pandangan mekanistik perilaku manusia yang mana keterampilan-keterampilan siswa dibangun melalui strategi pembelajaran yang spesifik (orientasi pembelajaran berbasis kompetensi).

Pendidikan merupakan sebuah rangkaian kejadian dan aktivitas yang dirancang untuk membantu individu untuk meningkatkan potensi pengetahuan, keterampilan dan nilainilai hidupnya. Maka menurut Nurdin (2014) kurikulum pada orientasi ini menekankan pada isi atau materi ajaran, isinya bersumber pada disiplin ilmu yang terstruktur dan sistematis, guru berfungsi sebagai pemberi arahan langsung dan penyampai ilmu, teknologi, dan nilai sehingga harus menguasai materi ajar dengan baik. Dan dalam orientasi transmisi ini ada gerakan satu arah dalam menyampaikan pengetahuan, keterampilan, nilai-nilai kepada siswa. ini, terutama ada gerakan satu arah untuk menyampaikan kepada siswa keterampilan, pengetahuan, dan nilai-nilai tertentu. 


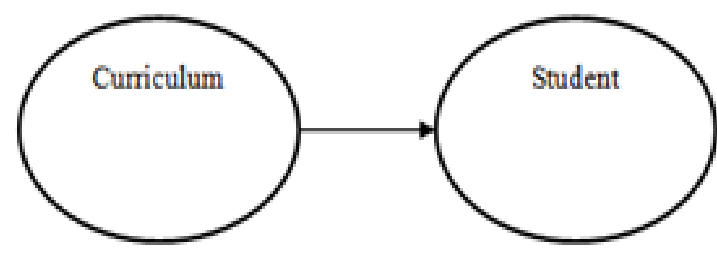

Gambar 1: Onientasi Transmisi

Berdasarkan gambar tersebut siswa merupakan penerima materi belajar dalam proses pembelajaran. Proses pembelajaran terjadi secara ekspositori. Menurut Rizal, Tayeb, Latuconsina (Rizal et al., 2016) metode Ekspositori adalah metode pembelajaran yang menekankan pada proses penyampaian materi secara verbal dari seorang guru kepada siswa dengan maksud agar siswa dapat menguasai materi pelajaran secara optimal. Selanjutnya evaluasi pembelajaran menggunakan prosedur tradisional seperti tes, uraian, multiple objective.

\section{Orientasi Transaksi Pengembangan Kurikulum \\ Orientasi ini berakar pada filsafat pendidikan John Dewey dan teori perkembangan. Dalam konteks orientasi}

transaksi individu dipandang rasional dan mampu menyelesaikan masalah secara cerdas. Pendidikan dipandang sebagai dialog antara siswa dan kurikulum di mana siswa merekonstruksi pengetahuan melalui proses dialog. Dalam konteks pengembangan kurikulum maka elemen utama dalam orientasi transaksi menekankan strategi kurikulum yang memfasilitasi siswa untuk memecahkan masalah (orientasi proses kognitif); penerapan keterampilan memecahkan masalah dalam konteks sosial secara umum dan dalam konteks proses demokrasi (orientasi kewarganegaraan demokratis); dan pengembangan keterampilan kognitif dalam disiplin ilmu (orientasi disiplin ilmu). Karena itu paradigma filosofis-ilmiah dalam orientasi transaksi adalah metode ilmiah. Gambar 2 menggambarkan posisi transaksi.

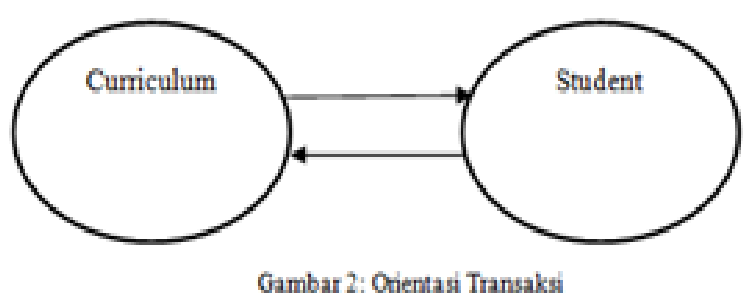

Gambar tersebut memperlihatkan adanya transaksi antara kurikulum dan peserta didik. Dalam orientasi transaksi peserta didik difasilitasi dan didorong untuk mendapatkan solusi dalam memecahkan masalah yang dihadapinya. Hal tersebut dapat ditempuh dengan proses demokrasi. Dengan orientasi demokrasi maka terjadi pemecahan masalah dalam berbagai mata pelajaran dengan berbagai tahapan kognitif. Orientasi transaksi dikaitkan 
dengan filsafat pragmatisme, perkembangan kognitif, dan politik liberalisme.

\section{Orientasi Transformasi Pengembangan Kurikulum}

Orientasi ini berakar pada dalam pemikiran postmodern, perspektif ekologis dan dalam perspektif kurikulum rekonstruksi sosial. Orientasi transformasi berfokus pada perubahan pribadi dan sosial. Hal mencakup tiga orientasi khusus: mengajar keterampilan siswa yang mempromosikan transformasi pribadi dan sosial (orientasi perubahan humanistik dan sosial); sebuah visi perubahan sosial sebagai gerakan menuju keharmonisan dengan lingkungan daripada sebagai upaya untuk melakukan kontrol atasnya, dan pengaitan dimensi spiritual dengan lingkungan di mana sistem ekologis dipandang dengan rasa hormat dan hormat (Miller and Seller, 1985). Paradigma orientasi transformasi merupakan konsepsi alam yang saling bergantung secara ekologis yang menekankan keterkaitan fenomena.

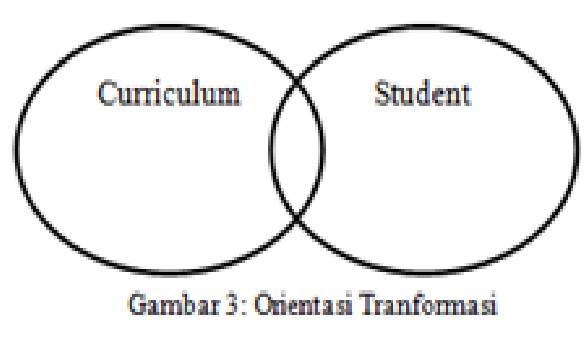

Dalam orientasi transformasi kurikulum dan siswa terlihat saling melakukan penetrasi secara holistik. Saling penetrasi antara kurikulum dan siswa pada satu sisi akan mendorong pengembangan diri siswa dan di sisi yang lain mendorong pula perubahan sosial kemasyarakatan. Maka orientasi transformasi menurut Nurdin (2014) menekankan pada pengajaran berbagai keahlian untuk memajukan transformasi pribadi dan sosial, visi perubahan sosial dan hubungan dimensi spiritual dengan lingkungan. Teori pendidikan yang digunakan adalah pendidikan progresif dan romantik, dengan model kurikulum humanistik.

Dalam pandangan Miller and Seller (1985), orientasi transformasi ini didasarkan pada dua pemikiran yang berbeda, yaitu orientasi elemen romantik dan orientasi

\section{METODE PENELITIAN}

Penelitian ini merupakan penelitian deskriptif kualitatif dimana metode yang digunakan adalah studi kepustakaan (library perubahan sosial. Pada orientasi romantik menekankan bahwa pada dasarnya anak itu baik dan tugas pendidik adalah mengembangkan berbagai potensi anak dan interferensi minimum. Orientasi ini berakar dalam pemikiran Rousseau dan juga ditemukan dalam karya Froebel, Tolstoy, A. S. Neill, dan John Holt. Sedangkan orientasi perubahan sosial berpendapat bahwa bahwa pendidik harus mengambil pandangan yang lebih kritis tentang peran sekolah dalam masyarakat sehingga sekolah tidak hanya mencerminkan kepentingan ekonomi yang dominan, sebaliknya sekolah harus berada di ujung tombak perubahan sosial dan politik. Orientasi ini tercermin dalam pandangan dan karya pendidik seperti Michael Apple, dan karya Friere di Brasil.

research) sesuai dengan fokus masalah yang dimunculkan. Furchan (Linarwati, Fathoni, Minarsih, 2016) berpendapat bahwa penelitian 
deskriptif adalah penelitian yang dirancang untuk memperoleh informasi tentang status suatu gejala saat penelitian dilakukan. Menurut Sugiyono (Ramanda et al., 2019) studi pustaka berkaitan dengan kajian teoritis dan beberapa referensi yang tidak akan lepas dari literaturliteratur ilmiah. Data-data diambiil dari berasal dari perpustakaan berupa buku, artikel jurnal dan sumber-sumber lain yang relevan dengan pengembangan kurikulum. Melalui buku

\section{HASIL DAN PEMBAHASAN}

Miller dan Seller mengidentifikasi dan menetapkan orientasi kurikulum utama, yaitu transmisi, transaksi, dan transformasi. Ketiga orientasi kurikulum dijelaskan dalam konteks pengembangan kurikulum di sekolah dasar. Pada dasarnya pengembang kurikulum di sekolah dasar mendesain kurikulum untuk diimplementasikan baik dalam dokumen instruksional, pelaksanaan kurikulum dalam proses pembelajaran di kelas, maupun dalam evaluasi pembelajaran untuk mengukur dan menilai hasil belajar siswa.

\section{Orientasi Transmisi Pengembangan Kurikulum Sekolah Dasar}

Fungsi pengembangan kurikulum sekolah dasar dalam konteks orientasi transmisi adalah mendesain bagaimana proses transmisi pengetahuan, keterampilan, dan sikap kepada siswa. Kurikulum didesain untuk menekankan pada konten atau materi pembelajaran yang bersumber pada disiplin ilmu yang terstruktur dan sistematis. Tujuan pengembangan kurikulum sekolah dasar adalah memfasilitasi siswa agar menguasai materi pengetahuan, keterampilan dan sikap berdasarkan berbagai sumber dan metode pembelajaran yang direncanakan oleh guru.

Pengembang kurikulum di sekolah dasar mendesain kurikulum yang secara konsisten mampu membantu siswa menguasai pengetahuan, keterampilan, dan sikap sesuai dengan tujuan pendidikan. Fungsi guru sekolah
Metodologi Penelitian Kepustakaan, Mestika Zed (Khatibah, 2011) mengemukakan empat langkah penelitian kepustakaan, yaitu menyiapkan alat perlengkapan, menyusun bibliografi kerja, mengatur waktu, dan membaca dan membuat catatan penelitian. Bibliografi kerja ialah catatan mengenai bahan sumber utama yang akan dipergunakan untuk kepentingan penelitian.

dasar adalah mentransfer pengetahuan. Artinya, guru sekolah dasar berperan sebagai pemberi arahan langsung dan penyampai ilmu pengetahuan, keterampilan, sikap dan nilai-nilai yang harus dikuasai oleh siswa dengan sebaikbaiknya.

Peran siswa sebagai penerima materi pembelajaran dan bekerja keras menguasai materi tersebut. menurut Depdiknas (Tuerah, 2015) materi pembelajaran dapat berupa (1) Bahan cetak seperti buku, hand out, modul, lembar kerja siswa, brosur, leaflet, wallchart; (2) Audio visual seperti video, film, VCD; (3) Audio seperti radio, kaset, $\mathrm{CD}$ audio, $\mathrm{PH}$; (4) visual seperti foto, gambar, model/maket; dan (5) multi media seperti CD interaktif, komputer based. Materi pembelajaran tersebut dapat berupa fakta, konsep, prinsip, prosedur, sikap atau nilai. Menurut Isdisusilo fakta, yaitu segala hal yang berwujud kenyataan dan kebenaran, seperti nama-nama obyek, peristiwa sejarah, lambang, nama tempat, nama orang, nama bagian atau komponen suatu benda. Konsep merupakan adalah segala yang berwujud pengertian-pengertian pengertian yang bisa timbul sebagai hasil pemikiran, meliputi definisi, pengertian, ciri khusus, hakikat, inti atau isi. Prinsip adalah hal-hal utama, pokok, dan memiliki posisi terpenting, meliputi dalil, rumus, adagium, postulat, paradigma, teorema, serta hubungan antar konsep yang menggambarkan implikasi sebab akibat. Prosedur merupakan langkah-langkah 
sistematis atau berurutan dalam mengerjakan suatu aktivitas dan kronologi suatu system. Sikap atau nilai merupakan hasil belajar aspek sikap, seperti kejujuran, kasih sayang, tolong menolong, semangat dan minat belajar dan bekerja (Churri \& Agung, 2013).

Proses pembelajaran dilaksanakan dengan metode ekspositori. Menurut Suyitno (Rachmawati, 2018) metode ekspositori ialah cara penyampaian pelajaran dari seorang guru kepada siswa di kelas dengan cara berbicara pada awal pembelajaran, menerangkan materi, memberikan contoh soal disertai tanya jawab dan siswa hanya mendengarkan dan membuat catatan. Metode pembelajaran ekspositori menekankan pada proses penyampaian secara verbal oleh guru agar siswa menguasai materi pembelajaran dengan maksimal. Kegiatan pembelajaran menggunakan strategi ekspositori cenderung berpusat kepada guru. Menurut David (Prayekti dan Rasyimah, 2013) metode ekspositori akan menjadi efektif dan efisien bila memenuhi syarat, yaitu: (1) belajar dengan menerima, jika materi yang disajikan kepada siswa lengkap hingga bentuk akhir baik berupa rumus atau pola bilangan; (2) belajar melalui penemuan, jika materi yang disajikan siswa tidak lengkap, bentuk akhir yang berupa rumus, pola, atau aturan ditemukan sendiri oleh siswa.

Evaluasi pembelajaran menggunakan dalam orientasi Miller-Seller adalah tradisional achievement seperti tes, uraian, pilihan ganda. Menurut Sudjana (Tarhadi, Kartono \& Yumiati, 2007) tes sebagai alat penilaian adalah pertanyaan-pertanyaan yang diberikan untuk mendapat jawaban dalam bentuk lisan, tulisan atau dalam bentuk perbuatan dari siswa. Penilaian tes dapat berupa tes pilihan ganda dan tes uraian dengan jawaban singkat dan uraian.

\section{Orientasi Transaksi Pengembangan Kurikulum Sekolah Dasar}

Dalam orientasi transaksi, pendidikan merupakan dialog antara kurikulum dan siswa di mana siswa mebentuk pengetahuannya melalui proses dialog karena sebab siswa memiliki kemampuan-kemampuan dasar seperti seperti kemampuan berpikir, menganaisis, mensintesa. Esensi dari pengembangan kurikulum dalam konteks transaksi adalah strategi kurikulum yang membantu siswa dalam pemecahan masalah, implementasi keterampilan memecahkan masalah didalam kehidupan nyata.

Pengembang kurikulum di sekolah dasar mendesain kurikulum untuk memungkinkan siswa mengeksplorasi kemampuannya dan mengaplikasikan berbagai perolehan pengetahuan, keterampilan dan sikap dalam realitas sosial yang nyata.

Strategi pembelajaran yang dikembangkan dalam pengembangan kurikulum adalah pendekatan ilmiah (scientific approach), dimana siswa membangun pengetahuan dan keterampilan melalui penerapan metode ilmiah dalam proses pembelajaran. Menurut Musfiqon dan Nurdyansyah (2015) pendekatan pembelajaran ilmiah merupakan bagian dari pendekatan pedagogis pada pelaksanaan pembelajaran dalam kelas yang melandasi penerapan metode ilmiah. Menurut Kementerian Pendidikan dan Kebudayaan (Sufairoh, 2016) pendekatan ilmiah di sekolah dasar meliputi lima langkah, yaitu: mengamati, menanya, mengumpulkan data, mengasosiasi, dan mengkomunikasikan.

Garu memiliki peran yang sangat penting dalam mempengaruhi efektifitas proses dan hasil belajar. Peran guru dalam orientasi transaksi adalah sebagai fasilitator bagi siswa untuk berinteraksi dengan sumber-sumber belajar yang tersedia. Guru merancang lingungan belajar yang kaya dengan ragam materi pembelajaran, merancang metode dalam proses pembelajaran yang memungkinkan terjadinya penyelidikan terhadap berbagai problem pembelajaran yang dihadapi oleh siswa. Menurut Condruta, B.E (Rahmawati \& Suryadi, 2019) guru sebagai fasilitator berarti mengizinkan siswa untuk menentukan kebutuhan dan tujuan pembelajaran mereka dan memanfaatkan berbagai sumber. Siswa aktif 
melakukan diskusi dan mencari pengalamanya sendiri melalui sistem, teknik dan metode belajar yang disediakan guru.

Evaluasi pemelajaran menerapkan evaluasi secara otentik dimana guru memonitor, mengukur, dan menulai seluruh pencapaian belajar siswa baik kognitif, afektif, maupun psikomotor. Menurut Mueller dan Palm (Ermawati \& Hidayat, 2017) penilaian ontentik adalah sebuah bentuk penilaian dengan meminta peserta didik untuk menunjukkan tugas dunia nyata yang mendemonstrasikan aplikasi yang bermakna dari pengetahuan dan keterampilan.

\section{Orientasi Transformasi Pengembangan Kurikulum Sekolah Dasar}

Karakteristik orientasi transformasi dalam pengembangan kurikulum di sekolah dasar adalah bahwa kurikulum dan siswa saling menyentuh secara holistik. Hal ini dimaksudkan agar tercipta proses dan hasil pengembangan pribadi siswa dan perubahan sosial. Siswa difasilitasi untuk melihat, memahami berbagai realitas dirinya dalam konteks soaial kemasyarakatan. Siswa bukan individu yang terpisah dari lingungan sosial melainkan pribadi yang terintegrasi dalam realitas sosial di sekitarnya. Maka pengembangan kurikulum dilaksanakan dengan tujuan mengembangkan transformasi pribadi dan sosial, visi perubahan sosial yang selaras dengan lingkungan sosial.

Dalam orientasi transformasi, Peran guru selain sebagai fasilitatr juga sebagai motivator. Guru memberikan motivasi kepada siswa dalam proses analisis dan integrasi dengan lingkungan sosial untuk terciptanya transformasi personal dan sosial. Guru memfasilitasi siswa untuk mengaktualisasikan berbagai potensi yang selaras dengan peran dalam lingkungan sosialnya. Pada dasarnya motovasi belajar siswa itu terdiri dari motivasi ekstrinsik dan motivasi intrinsik. Peran utama guru adalah mendorong tumbuhnya motivasi intrinsik siswa, karena motivasi intrinsic merupakan pendorong utama dalam belajar setiap siswa. Menurut Djamarah (Sugiasih, 2015) motivasi tersebut dapat ditumbuhan oleh siswa manakala guru melayani kebutuhan setiap siswa sehingga siswa lebih tertarik dalam belajar. Sedangkan menurut Sardiman (Sundari, 2017) peran sebagai motivator sangat penting untuk meningkatkan kegairahan dan pengembangan kegiatan belajar siswa. Guru memberikan rangsangan, dorongan serta reinforcement untuk mengembangkan potensi siswa, menumbuhkan aktivitas dan kreativitas sehingga akan terjadi dinamika dalam proses belajar.

Untuk itu guru menerapkan pendekatan pembelajaran seperti collaborative learning, partisipative learning, inquiry learning agar siswa dapat menemukan makna dan nilai materi dan proses pembelajaran yang dijalaninya. Siswa menjalankan peran mengeksplorasi, mengaktiialisasikan berbagai kemampuannya serta memahami berbagai realitas yang ada dan terjadi dalam lingkungannya. Menurut Dillenbourg (Apriono, 2013) collaborative learning sebagai sebuah metode pembelajaran menekankan pada tugas spesifik dan berbagi tugas dalam kerja kelompok, membandingkan kesimpulan dan prosedur kerja kelompok, dan memberikan keleluasaan yang lebih besar pada peserta didik dalam kerja kelompok. Selanjutnya menurut Rjusman (Taufik et al., 2014) pembelajaran partisipatif pada intinya dapat diartikan pembelajaran yang melibatkan peserta didik dalam kegiatan pembelajaran secara optimal. Pembelajaran ini menitikberatkan pada keterlibatan peserta didik pada kegiatan pembelajaran bukan pada dominasi guru dalam penyampaian materi pembelajaran. Demikian juga Hartono (Asmayani, 2014) mendeskripsikan pembelajaran inquiry sebagai belajar mencari dan menemukan sendiri, dengan mengikuti langkah-langkah seperti orientasi, merumuskan masalah, mengajukan hipotesis, mengumpulkan data, menguji hipotesis dan merumuskan kesimpulan. 


\section{PEMBAHASAN}

Pembahasan ini lebih pada mengulas ketiga orientasi pengembangan kurikulum berdasarkan berbagai tinjauan dengan tujuan memperdalam pemahaman terhadap ketiga orientasi tersebut. Miller dan Seller menyatakan bahwa orientasi pengembangan kurikulum adalah orientasi transmisi, transaksi, dan transformasi.

\section{Dimensi Orientasi Transmisi Pengembangan Kurikulum Sekolah Dasar \\ Orientation transmisi memandang} siswa sebagai individu yang pasif dan guru sebagai pemberi tugas (taskmaster). Tugas ini harus dikerjakan siswa untuk memperoleh nilai. Proses pembelajaran berpusat pada guru. Pengalaman belajar terjadi melalui pengiriman atau transfer fakta, konsep, aturan, dan norma budaya dari guru ke siswa (Cervatiuc and Ricento, 2012: 19). Karena itu menurut Pinet (2006) tujuan pengembangan kurikulum adalah penguasaan mareri pembelajaran dan penanaman norma-norma sosial. Siswa diharapkan untuk mempelajari fakta dan konsep dalam lingkungan yang terstruktur di mana guru memainkan peran sebagai pengarah. Evaluasi hasil belajar siswa didasarkan pada tes prestasi.

Bertolak dari orientasi tersebut maka implikasi pengembangan dan implementasi kurikulum di sekolah dasar adalah Pertama, kurikulum yang dikembangkan adalah kurikulum subjek akademik dengan penekanan pada organisasi kurikulum mata pelajaran (subject centered curriculum)). Menurut Zainal Arifin (Sugiana, 2018) dalam subject centered curriculum tersebut materi pembelajaran dikemas dan disajikan secara terpisah-pisah seolah-olah ada batasan antara mata pelajaran yang sama dikelas yang berbeda. Tujuan utama adalah siswa mengusai pengetahuan. Transmisi pengetahuan, keterampilan, nilai-nilai didesain dalam mata pelajaran. Pengetahuan, keterampilan, nilai-nilai yang dikemas dalam mata pelajaran yang harus dikusai oleh siswa sesuai dengan arahan guru dalam proses pembelajaran. Kedua, proses pembelajaran berpusat pada guru (teacher centered learning). Guru membuat semua keputusan mengenai kurikulum yang mencakup metode, sumber belajar, media, penilaian, dan sebagainya siswa tidak diberi kebebasan dan tanggung jawab dalam mengembangkan pengetahuan (Prasetya, 2014). Pengalaman belajar terjadi melalui transfer pengetahuan dari guru ke siswa. Ketiga, peran guru sekolah dasar menjadi sangat dominan. Guru atau pengembang kurikulum dipandang memiliki pengetahuan, keterampilan, dan sikap yang diinginkan. Sebaliknya, siswa dipandang kurang dan membutuhkan pengetahuan, keterampilan, pengetahuan, dan sikap yang diinginkan. Guru harus menjadi model dan pengarah dalam proses pembelajaran. Karena itu menurut Garrett (2008) guru cenderung sangat mengontrol, menggunakan sanksi hukuman, persepsi moralistik, hubungan yang sangat impersonal dengan siswa, sikap ketidakpercayaan umum dan fokus besar pada pemeliharaan ketertiban. Keempat, evaluasi pembelajaran menggunakan cara tradisional yaitu tes hasil belajar. Sebenarnya tes hasil belajar bertujuan untuk mengukur keberhasilan siswa dalam menguasai indikator - indikator kompetensi, dengan melihat hasilnya guru akan mengetahui kelemahan siswa (Osnal, Suhartoni, 2016).

\section{Dimensi Orientasi Transaksi Pengembangan Kurikulum Sekolah Dasar}

Dalam orientasi transaksi ini siswa dipandang sebagai individu aktif dan rasional. Proses pembelajaran berfokus pada mendorong pertumbuhan dan perkembangan peserta didik dan kemampuan pemecahan masalah berdasarkan pengetahuan yang dikonstruksi oleh siswa dalam interaksi dengan lingkungan. Dalam hal ini pengalaman, kebutuhan, motivasi siswa dalam pembelajaran mempengaruhi pandangannya tentang apa yang pantas dan 
menarik untuk dipelajarinya. Hal ini sejalan dengan Cervatiuc dan Ricento (2012) bahwa proses pendidikan berfokus pada pemecahan masalah dan penemuan. Siswa membangun pengetahuan dan mengembangkan keterampilan dengan terlibat dalam dialog dengan materi pendidikan, teman sebaya, dan guru yang bertindak sebagai fasilitator atau moderator. Cirikhas orientasi ini adalah adanya saling interaksi antara kurikulum dengan siswa dalam proses pembelajaran untuk mencapai tujuan pembelajaran yang telah ditetapkan.

Bertolak dari orientasi tersebut maka pengembangan dan implemmentasi kurikulum di sekolah dasar adalah Pertama, tujuan pembelajaran dalam pengembangan kurikulum diarahkan kepada pembentukan pengetahuan dan keterampilan peserta didik. Siswa mengkonstruksi pengetahuan, keterampilan dan nilai melalui proses pembelajaran. Pengembangan kurikulum di sekolah dasar membantu dan memfasilitasi siswa untuk membentuk sendiri penggetahuan, keterampilan dan nilai-nilai hidup melalui berbagaia strategi pembelajaran. Untuk maksud tersebut menurut Aunurahman (Ernawati, 2018) siswa harus memiliki kemampuan memperdayakan berbagai fungsi dalam dirinya seperti (1) kemampuan mengingat dan mengungkapkan kembali pengalaman; (2) kemampuan membandingkan, mengambil keputusan mengenai persamaan dan perbedaan; (3) kemampuan lebih menyukai pengalaman yang satu dari pada pengalaman yang lain. Kedua, Proses pembelajaran aktif dan kolaboratif.

Kolaboratif ini terjadi antara siswa dengan guru, siswa dengan rekannya, dan siswa dengan berbagai sumber belajar. Pembelajaran aktif dan kolaboratif memberdayakan siswa untuk mengolah materi pembelajaran dan memecahkan masalah yang dihadapinya. Meyersand Jones menyatakan bahwa "active learning derives from two basic assumptions: (a) that learning is by its very nature an active process and (b) that different people learn in differentways" (Effendi, 2013).
Artinya bahwa pembelajaran pada dasarnya adalah pencarian secara aktif pengetahuan dan setiap orang belajar dengan cara yang berbeda. Sedangkan pembelajaran kolaboratif lebih memberi perhatian pada proses pembelajaran secara bersama-sama antar siswa. Hal ini selaras dengan pendapat Wiersma (Susanti et al., 2017) bahwa collaborative learning is philosophy: working together, building together, learning together, improving together. Dalam hal ini filosofi pembelajaran kolaboratif adalah bekerja sama, membangun pengetahuan bersama, melakukan perubahan pengetahuan bersama, dan mengalami peningkatan bersamasama. Dalam kegiatan pembelajaran Setyosari (Apriono, 2013) mengatakan bahwa ada beberapa keunggulan pembelajaran kolaborasi yaitu (1) prestasi belajar lebih tinggi, (2) pemahaman lebih mendalam, mengembangkan keterampilan kepemimpinan, (5) meningkatkan sikap positif, meningkatkan harga diri, (7) belajar secara inklusif, (8) merasa saling memiliki, dan (9) mengembangkan keterampilan masa depan.

Ketiga, metode dan strategi pembelajaran ilmiah (saintifik). Orientasi transaksi yang berfokus pada pemecahan masalah dan penemuan relevan degan desain kurikulum berbasis pendekatan saintifik atau pendekatan ilmiah. Melalui pendekatan saintifik siswa dalam mengembangkan kompetensi melakukan observasi atau eksperimen melaikan mengembangkan pengetahuan dan keterampilan berpikir sehingga dapat mendukung aktivitas kreatif dalam berinovasi atau berkarya (Musfiqon dan Nurdyansyah, 2015).

Keempat, peran guru sekolah dasar sebagai fasilitator. Dalam orientasi transaksi guru mengambil peran sebagai fasilitator pembelajaran. Peran guru sebagai fasilitator adalah memberikan motivasi, memfasilitasi siswa dalam belajar sehingga membangkitkan semangat belajar siswa. Artinya, tugas guru tidak hanya menyampaikan informasi kepada siswa melainkan menjadi fasilitator yang memberikan kemudahan belajar (facilitate of 
learning) agar siswa dapat belajar dalam suasana yang menyenangkan, gembira, penuh semangat, tidak cemas, dan berani mengemukakan pendapat secara terbuka (Mulyasa, 2013).

Kelima, evaluasi pembelajaran autentik. Pendekatan saintifik dengan metode problem solving approach dan inquiry approach dalam pembelajaran menuntut metode evaluasi autentik. Menurut Muller (Ermawati \& Hidayat, 2017) bahwa dalam penilaian autentik guru mengukur, memonitor dan menilai semua aspek hasil belajar siswa (kognitif, afektif, dan psikomotor), baik hasil belajar yang dicapai dalam akhrir pembelajaran maupun berbagai perubahan dan perkembangan serta hasil belahar yang diperoleh selama proses pembelajaran didalam kelas maupun diluar kelas.

\section{Dimensi Orientasi Transformasi Pengembangan Kurikulum Sekolah Dasar}

Orientasi transformasi mengajarkan keterampilan dan pengetahuan siswa yang mendorong transformasi pribadi dan sosial. Orientasi ini meningkatkan kesadaran sosial dan memberdayakan siswa untuk berpartisipasi dalam masyarakat dan melampaui sikap do their own thing. Pengembangan kurikulum cenderung mengintegrasikan dunia dalam dan luar, membuat siswa sadar akan hubungannya dengan dunia luar, dan mendorong aktualisasi diri, kegiatan interdisipliner, dan keterlibatan dalam masyarakat (Cervatiuc \& Ricento, 2012). Dalam orientasi transformasi ini ada interkoneksivisme filosofis, psikologi transpersonal, dan aktivisme politik untuk perubahan sosial. Dan hal ini memotivasi siswa menjadi lebih terlibat secara sosial untuk mengubah kehidupan dan masyarakat keseluruhan secara positif.

Dalam pandangan Miller dan Seller (Nurdin, 2014) implementasi kurikulum merupakan implementasi konsep, ide, program, atau tatanan kurikulum ke dalam praktek pembelajaran sehingga terjadi perubahan pada diri siswa atau sekelompok siswa yang diharapkan berubah. Maka implementasi orientasi transformasi dalam pengembangan kurikulum meliputi pertama, tujuan pembelajaran dalam kurikulum adalah terjadinya transformasi pribadi dan sosial siswa. Artinya, ada perubahan yang dialami siswa baik dalam dirinya maupun dalam lingkungan sosialnya. Adanya perubahan ini sangat berkaitan dengan nilai atau makna yang ditemukan siswa melalui proses pembelajaran. Nilai sebagai esensi transformasi memberi pijakan dana arah kepada siswa baik terkait dirinya maupun terkait lingkungan sosialnya. Senada dengan hal tersebut Bertens (Sudjatnika, 2017) mengatakan bahwa nilai setidaknya memiliki tiga kategori yaitu nilai berkaitan dengan subyek, nilai dalam suatu konteks praktik, dan nilai menyangkut sifat-sifat yang ditambah oleh subyek pada sifat-sifat yang dimiliki oleh objek. Hal ini berarti transformasi sebagai tujuan pengembangan kurikulum tercapai dalam diri siswa dan dalam konteks sosialnya. Pengembangan kutrikulum di sekolah dasar terarah pada penemuan nilai dan makna yang mendorong siswa melakukan transformasi pribadi dan sosial.

Kedua, pengembangan kurikulum di sekolah dasar menerapkan strategi pembelajaran yang mendorong siswa menemukan makna dan nilai serta menerapkannya baik dalam proses pembelajaran di sekolah maupun dalam kehidupan sehari-hari di luar sekolah. maka strategi pembelajaran yang relevan antara lain collaborative learning, partisipative learning, inquiry learning. Melalui pembelajaran kolaboratif siswa bersama-sama menemukan nilai dan makna semua kegiatan pembelajarannya. Pembelajaran partisipatif akan mendorong siswa untuk terlibat dalam kondisi-kondisi atau masalah-masalah riil yang dijupainya. Menurut Knowles (Setiawan, 2017) indikator pembelajaran partisipatif antara lain adanya keterlibatan emosional dan mental peserta didik; adanya kesediaan peserta didik 
untuk memberikan kontribusi dalam pencapaian tujuan; dan dalam kegiatan belajar tersebut terdapat hal yang menguntungkan siswa. Pembelajaran inkuiri akan mendorong siswa menemukan nilai-nilai hidup, aspek-aspek transformasi personal dan sosial. Penemuan tersebut memberi kesadaran dan dorongan kepada siswa untuk berpartisipasi dalam pemecahan masalah-masalah kehidupan. Pembelajaran inkuiri akan memberi kualitas pembelajaran dan penemuan makna dan nilai yang diaplikasihkan dalam kehidupan siswa. Dikatakan bahwa pembelajaran inkuiri merupakan proses pembelajaran yang menekankan pada proses bepikir kritis dan analitis untuk mencari dan menemukan sendiri jawaban dari suatu masalah (Mulyono, 2011).

Ketiga, peran guru sekolah dasar sebagai motivator dan fasilitator. Sebagai motivator pembelajaran guru membantu siswa meningkatkan kegairahan dan pengembangan kegiatan belajara siswa. Dalam hal ini guru memberikan stimulus dan penguatan sehingga terjadi dinamika dalam proses pembelajaran. Sebagai fasilitator, guru memberikan fasilitas atau kemudahan dalam proses pembelajaran sehingga interaksi pembeajaran berlangsung secara efektif dan optimal (Sundari, 2017). Dengan menjalanpan peran sebagai motivator dan fasilitator pembelajaran maka guru telah menempatkan siswa sebagai pusat pembelajaran. Siswa menjadi subyek pembellajaran yang berinteraksi dengan semua sumber belajar untuk mengembangkan dirinya.

\section{SIMPULAN DAN REKOMENDASI}

Orientasi pengembangan kurikulum dalam pandangan Miller dan Seller adalah orientasi transmisi, transaksi, dan transformasi. Pengembangan kurikulum di sekolah dasar. Dalam konteks orientasi transmisi maka pengembangan kurikulum di sekolah dasar kurikulum yang dikembangkan adalah kurikulum subjek akademik dengan penekanan
Keempat, evaluasi pembelajaran berbasis penilaian autentik. Dengan strategi pembelajaran seperti collaborative learning, partisipative learning, inquiry learning dimana siswa dapat mengeksplorasi berbagai kemampuannya maka perlu diterapkan evaluasi pembelajaran yang menilai seluruh kemampuan siswa. Dalam konteks ini sangat tepat diterapkan penilaian otentik satu asesmen hasil belajar yang menuntut siswa menunjukkan prestasi dan hasil belajar berupa kemampuan dalam kehidupan nyata dalam bentuk kinerja (Supardi, 2015). Dalam melaksanakan

penilaian dan evaluasi guru perlu memperhatikan prinsip-prinsip penilaian, yaitu valid atau sahih, obyektif, transparan atau terbuka, adil, terpadu, menyeluruh, sistematis, akuntabel, beracuan kriteria (Ginting \& Permana, 2018). Hal ini sesuai dengan Permendikbud nomor 66 tahun 2013 bahwa penilaian hasil belajar peserta didik pada jenjang pendidikan dasar dan menengah didasarkan pada prinsip-prinsip objektif, terpadu, ekonomis, transparan, akuntabel, edukatif. Menurut Zainal Arifin (Umami, 2018) penilaian proses dan hasil belajar dibagi menjadi empat jenis yaitu penilaian formatif, penilaian sumatif, penilaian penempatan, dan penilaian diagnostik. Dijelaskan bahwa penilaian formatif. Dengan demikian, melalui penilaian autentik yang juga menjadi cirikhas penilain pembelajaran dalam kurikulum 2013 maka guru dapat mengetahui berbagai kemampuan siswa dan menilainya secara tepat dan komprehensif.

pada organisasi kurikulum secara nampak dalam pengembangan kurikulum subjek akademik yang menekankan organisasi kurikulum secara terpadu (integrated curriculum model), proses pembelajaran berpusat pada guru (teacher centered learning), peran guru sangat dominan (guru sebagai pengarah). Pengembangan kurikulum dalam 
orientasi transaksi nampak dalam tujuan pembelajaran diarahkan pada pembentukan pengetahuan dan keterampilan siswa, proses pembelajaran aktif dan kolaboratif, metode dan strategi pembelajarann saintifik (ilmiah), peran guru sebagai fasilitator, evaluasi pembelajaran autentik. Akhirnya, orientasi transformasi nampak dalam tujuan pembelajaran yang mengarah kepada transformasi pribadi dan sosial, penerapan strategi pembelajaran yang mendorong siswa menemukan makna dan nilai serta menerapkannya, peran guru sebagai motivator dan fasilitator, dan evaluasi pembelajaran berbasis penilaian autentik.

Berdasarkan uraian di atas penulis merekomendasikan agar ketiga orientasi kurikulum Miller dan Seller dapat

\section{UCAPAN TERIMA KASIH}

Penulis mengucapkan terima kasih kepada Prodi PGSD STKIP Weetebula Sumba Barat Daya NTT, Program Studi Pengembangan Kurikulum Sekolah Pasca

\section{DAFTAR PUSTAKA}

Andiyanto, T. (2017). Peran Guru Dalam Implementasi Kurikulum 2013: Studi Pada TK Mentari Kec. Abung Selatan Kab. Lampung Utara. Elementary: Jurnal Ilmiah Pendidikan Dasar, 3(1), 73-78.

https://doi.org/10.32332/elementary.v3i 1.790

Apriono, D. (2013). Pembelajaran Kolaboratif: Suatu Landasan untuk Membangun Kebersamaan dan Keterampilan. Diklus, 17(1), 292-304.

Asmayani, D. (2014). Model Pembelajaran Inquiry dan Hasil Belajar Siswa Pada Mata Pelajaran Aqidah Akhlak Kelas VIII MTS Negeri Tebing Tinggi Empat Lawang. Ta'dib, 19(1), 43-62. diimplementasikan secara eklektikal dan proporsional dalam pengembangan kurikulum di sekolah dasar sesuai dengan kebutuhan siswa dan karakteristik kurikulum sekolah dasar. Pengalaman belajar siswa sekolah dasar tidak hanya terjadi dari interaksi guru dan siswa melainkan dari interaksi siswa dengan berbagai sumber belajar. Pengembangan kurikulum di sekolah dasar perlu memfasilitasi interaksi saling mempengaruhi antara kurikulum dan siswa agar memperlancar konstruksi pengetahuan, keterampilan dan nilai-nilai bagi siswa. Dan akhirnya, pengembangan kurikulum di sekolah dasar perlu diarahkan kepada transformasi personal dan sosial siswa dalam rangka pemaknaan hidup pribadi dalam konteks praksis hidup siswa.

Sarjana Universitas Pendidikan Indonesia Bandung, Komunitas Priorat Pratista Kumara Warabrata Sultan Agung Bandung atas kerjasama dan dukungan dalam penelitian ini.

Bahri, S. (2011). Pengembangan Kurikulum Tujuan Dasar dan Tujuannya. Jurnal Ilmiah Islam Futura, 11(1), 1-20.

Cervatiuc, A., \& Ricento, T. (2012). Curriculum Meta-Orientations in the Language Instruction For Newcomers to Canada program. The Canadian Journal for the Study of Adult Education, 24(2), 17-31.

Churri, M., \& Agung, Y. (2013). Pengembangan Materi Dan Media Pembelajaran Mata Pelajaran Dasar Kompetensi Kejuruan Teknik Audio Video Untuk SMK Negeri 7 Surabaya. Jurnal Pendidikan Teknik Elektro, 2(2), 803-809.

Effendi, M. (2013). Integrasi Pembelajaran Active Learning dan Internet-Based Learning dalam Meningkatkan 


\section{PRIMARY: JURNAL PENDIDIKAN GURU SEKOLAH DASAR VOLUME 9 NOMOR 5 OKTOBER 2020 \\ ISSN: 2303-1514 | E-ISSN: 2598-5949 \\ DOI : http://dx.doi.org/10.33578/jpfkip.v9i5.7987 \\ https://primary.ejournal.unri.ac.id/index.php/JPFKIP}

Keaktifan dan Kreativitas Belajar. Nadwa: Jurnal Pendidikan Islam, 7(2), 283-308.

https://doi.org/10.21580/nw.2013.7.2.5 63

Ermawati, S., \& Hidayat, T. (2017). Penilaian Autentik Dan Relevansinya Dengan Kualitas Hasil Pembelajaran (Persepsi Dosen dan Mahasiswa IKIP PGRI Bojonegoro). Jurnal Pendidikan Ilmu Sosial, 27(1), 92-103.

Ernawati, M. (2018). Penggunaan Metode Pendekatan Ketrampilan Proses Untuk Meningkatkan Aktivitas Hasil Belajar Ipa Siswa Kelas Iii Sekolah Dasar. Primary: Jurnal Pendidikan Guru Sekolah Dasar, 7(1), 75-87. https://doi.org/10.33578/jpfkip.v7i1.53 50

Garrett, T. (2008). Student-Centered and Teacher-Centered Classroom Management: A Case Study of Three Elementary Teachers. Journal of Classroom Interaction, 43(1), 34-47.

Ginting, E \& Permana, Y. (2018). Ginting, E dan Permana, Y. (2018). Pedagogi: Penilaian Evaluasi Proses dan Hasil Belajar. Jakarta: Direktorat Jenderal Guru dan Tenaga Kependidikan Kementerian Pendidikan dan Kebudayaan. Direktorat Jenderal Guru dan Tenaga Kependidikan Kementerian Pendidikan dan Kebudayaan.

Hadijaya, Y. (2015). Pengembangan Kurikulum Integratif Pendidikan Dasar Dan Menengah Menuju Pembelajaran Efektif Sebuah Analisis Kritis. Jurnal Tarbiyah, 22(2), 280-312.

Khatibah. (2011). Penelitian Kepustakaan. Jurnal IIqra', 05(01), 36-39.

Linarwati M, Fathoni A, Minarsih, M. M. (2016). Studi Deskriptif Pelatihan Dan Pengembangan Sumberdaya Manusia Serta Penggunaan Metode Behavioral Event Interview Dalam Merekrut Karyawan Baru Di Bank Mega Cabang Kudus. Journal of Management, 2(2), $1-8$. https://doi.org/10.1016/j.bpc.2013.02.0 04

Miller, John. P and Seller, W. (1985). Curriculum Perspectives and Practice. New York \& London: Longman.

Mulyasa, E. (2013). Standar Kompetensi dan Sertifikasi Guru. Bandung: Remaja Rosdakarya.

Mulyono. (2011). Strategi Pembelajaran Menuju Efektivitas Pembelajaran di Abad Global. Malang: (UIN- Maliki Press.

Munandar, A. (2017). Kurikulum Sebagai Jantung Pendidikan. Prosiding Seminar Nasional Pendidik Dan Pengembang Pendidikan Indonesia Dengan Tema "Membangun Generasi Berkarakter Melalui Pembelajaran Inovatif" . Aula Handayani IKIP Mataram 14 Oktober 2017, 52-61.

Musfiqon dan Nurdyansyah. (2015). Pendekatan Pembelajaran Saintifik. Sidoarjo: Nizamia Learning Center.

Ndeot, F. (2019). Pentingnya Pengembangan Kurikulum di PAUD. Jurnal Lonto Leok Pendidikan Anak Usia Dini, 2(1), 30-36.

Nur, A. (2006). Konsep Dan Teori Kurikulum Dalam Dunia Pendidikan. Islamica, 1(1), 12-29.

Nurdin, S. (2014). Model Kurikulum Miller Seller Dan Pengembangannya. Jurnal Al-Fikrah, 2(1), 19-26.

Oliva, Peter F and Gordon, W. (2013). Developing the Curriulum. Boston: Pearson.

Ornstein, A. C., \& Hunkins, F. P. (2018). Curriculum: Foundation, Principles and Issue (7th Editio). london: Pearson.

Osnal, Suhartoni, I. W. (2016). Meningkatkan Kemampuan Guru dalam Menyusun Tes Hasil Belajar Akhir Semester melalui Workshop di KKG Gugus 02 Kecamatan Sumbermalang Tahun 2014/2015. Pancaran, 5(1), 67-82.

Pinet, R. (2006). The Contestation of Citizenship Education at Three Stages of the LINC 4 \& 5 Curriculum 
Guidelines: Production, Reception, and Implementation. TESL Canada Journal, 24(1), $1-20$. http://eric.ed.gov/ERICWebPortal/recor dDetail?accno=EJ815740

Prasetya, S. P. (2014). Memfasiltasi Pembelajaran Berpusat Pada Siswa. Jurnal Geografi, 12(1), 1-12.

Prayekti dan Rasyimah. (2013). Pengaruh Pembelajaran Kooperatif STAD versus Ekspositori Terhadap Hasil Belajar Pemahaman dan Aplikasi Konsep IPA Siswa kelas IV Sekolah Dasar. Jurnal Pendidikan Dan Kebudayaan, 19(4), 451-471.

Rachmawati, T. K. (2018). Pengaruh Metode Ekspositori Pada Pembelajaran Matematika Dasar Mahasiswa Manajemen Pendidikan Islam. JPE: Jurnal Pendidikan Edutama, 5(1), 5155.

https://doi.org/10.30734/jpe.v5i1.130

Rahmawati, M. dan, \& Suryadi, E. (2019). Guru Sebagai Fasilitator dan Efektivitas Belajar Siswa. Jurnal Pendidikan Manajemen Perkantoran, 4(1), 49-54. https://doi.org/10.17509/jpm.v4i1.1495 4

Ramanda, R., Akbar, Z., \& Wirasti, R. A. M. K. (2019). Studi Kepustakaan Mengenai Landasan Teori Body Image Bagi Perkembangan Remaja. Jurnal Edukasi: Jurnal Bimbingan Konseling, 5(2), 120-135. https://doi.org/10.22373/je.v5i2.5019

Rizal M., Tayeb, T., \& Latuconsina, N. (2016). Efektivitas Penerapan Metode Ekspositori Berbasis Kuis Terhadap Hasil Belajar Matematika Siswa Kelas VIII MTsN Ma'rang Kabupaten Pangkep. MaPan: Jurnal Matematika Dan Pembelajaran, 4(2), 172-185. https://doi.org/10.24252/mapan.2016v4 n2a2

Setiawan, W. E. (2017). Model Pembelajaran Partisipatif Dalam Meningkatkan Kemandirian Perempuan Sebagai
Kepala Keluarga. Jurnal Pendidikan Non Formal Dan Informal, 7(2), 1-15.

Shofiyah. (2018). Prinsip - Prinsip Pengembangan Kurikulum dalam Upaya Meningkatkan Kualitas Pembelajaran. Edureligia: Jurnal Pendidikan Agama Islam, 2(2), 122130.

https://doi.org/10.33650/edureligia.v2i2 .464

Sudjatnika, T. (2017). Nilai-Nilai Karakter Yang Membangun Peradaban Manusia. Al-Tsaqafa: Jurnal Ilmiah Peradaban Islam, 14(1), 133-146. https://doi.org/10.15575/altsaqafa.v14i1.1796

Sufairoh. (2016). Pendekatan Saintifik dan Model Pembelajaran K-13. Jurnal Pendidikan Profesional, 5(3), 116-125.

Sugiana, A. (2018). Proses Pengembangan Organisasi Kurikulum Dalam Meningkatkan Pendidikan Di Indonesia. Jurnal Pendagogik, 05(02), 257-273.

https://ejournal.unuja.ac.id/index.php/p edagogik

Sugiasih, P. (2015). Pengaruh Peran Guru Sebagai Motivator Terhadap Motivasi Belajar Ekonomi Siswa SMA SeKecamatan Seririt Tahun Pelajaran 2014 / 2015. Jurnal Jurusan Pendidikan Ekonomi, 5(1), 1-11.

Sundari, F. (2017). Peran Guru Sebagai Pembelajar Dalam Memotivasi Peserta Didik Usia SD. Prosiding Diskusi Panel Pendidikan "Menjadi Guru Pembelajar" Keluarga Alumni Universitas Indraprasta PGRI, (April), 60-76.

Supardi. (2015). Penilaian Autentik. Jakarta: RajaGrafindo Persada.

Susanti, S., Prasetyo, T., \& Nasution, S. A. (2017). Model Pembelajaran Kolaboratif Sebagai Alternatif Pembelajaran Ilmu Pengetahuan Sosial. Didaktika Tauhidi: Jurnal Pendidikan Guru Sekolah Dasar, 4(1), 19-30. https://doi.org/10.30997/dt.v4i1.822 


\section{PRIMARY: JURNAL PENDIDIKAN GURU SEKOLAH DASAR \\ VOLUME 9 NOMOR 5 OKTOBER 2020 \\ ISSN: 2303-1514 | E-ISSN: 2598-5949 \\ DOI : http://dx.doi.org/10.33578/jpfkip.v9i5.7987 \\ https://primary.ejournal.unri.ac.id/index.php/JPFKIP}

Tarhadi, Kartono, \& Yumiati. (2007). Penggunaan Tes Uraian Dibandingkan Dengan Tes Pilihan Ganda Terstruktur dan Tes Pilihan Ganda Biasa. Jurnal Pendidikan, 8(2), 102-109.

Taufik, R., Hustim, R., \& Nurlina. (2014). Penerapan Pembelajaran Partisipatif Metode True-False Dalam Pembelajaran Fisika Pada Siswa Kelas VIIB SMP Negeri 17 Bulukumba. Jurnal Pendidikan Fisika Unismuh, 2(3), 245-260.

Tuerah, R. M. S. (2015). Penguasaan Materi

Pembelajaran, Manajemen dan Komitmen Menjalankan Tugas Berkorelasi Pada Kinerja Guru SD Di Kota Tomohon. Jurnal Inovasi dan Teknologi Pembelajaran, 1(2), 137154.

Umami, M. (2018). Penilaian Autentik Pembelajaran Pendidikan Agama Islam dan Budi Pekerti dalam Kurikulum 2013. Jurnal Kependidikan, 6(2), 222232.

https://doi.org/10.24090/jk.v6i2.2259

Wafi, A. (2017). Konsep Dasar Kurikulum Pendidikan Agama Islam. Edureligia: Jurnal Pendidikan Agama Islam, 1(2), 133-139.

https://doi.org/10.33650/edureligia.v1i2 .741

Wahyuni, S. (2016). Curriculum Development in Indonesian Context the Historical Perspectives and the Implementation. Universum, 10(1), 73-78. https://doi.org/10.30762/universum.v10 i1.225

Winarso, W. (2017). Dasar Pengembangan Kurikulum Sekolah. Cirebon: IAIN Syekh Nurjati.

Zulhafizh. (2020). Orientation On Implementation of Learning Curriculum at Senior High School: Teacher's Perspective. Jurnal Pajar: Pendidikan dan Pengajaran, 4(2), 303315. 